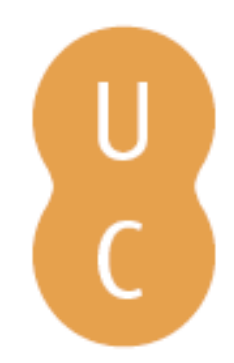

\title{
pommalina
}

The stakes of diversity and sexual selection: on normative commitments in evolutionary biology
Autor(es):
Nunes, João Arriscado
Publicado por: Imprensa da Universidade de Coimbra
URL
persistente:
URI:http://hdl.handle.net/10316.2/31290
DOI:
DOI:http://dx.doi.org/10.14195/978-989-26-0342-1_16
Accessed : $\quad$ 26-Apr-2023 13:18:19

A navegação consulta e descarregamento dos títulos inseridos nas Bibliotecas Digitais UC Digitalis, UC Pombalina e UC Impactum, pressupõem a aceitação plena e sem reservas dos Termos e Condições de Uso destas Bibliotecas Digitais, disponíveis em https://digitalis.uc.pt/pt-pt/termos.

Conforme exposto nos referidos Termos e Condições de Uso, o descarregamento de títulos de acesso restrito requer uma licença válida de autorização devendo o utilizador aceder ao(s) documento(s) a partir de um endereço de IP da instituição detentora da supramencionada licença.

Ao utilizador é apenas permitido o descarregamento para uso pessoal, pelo que o emprego do(s) título(s) descarregado(s) para outro fim, designadamente comercial, carece de autorização do respetivo autor ou editor da obra.

Na medida em que todas as obras da UC Digitalis se encontram protegidas pelo Código do Direito de Autor e Direitos Conexos e demais legislação aplicável, toda a cópia, parcial ou total, deste documento, nos casos em que é legalmente admitida, deverá conter ou fazer-se acompanhar por este aviso.

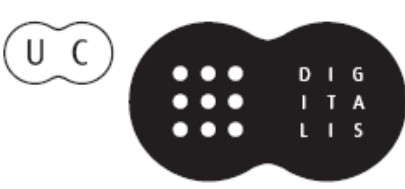


Ana Leonar Pereira João Rui Pita

Pedro Ricarda Fonseca (eds.)
Darwin,

Evalution,

Evolutionisms

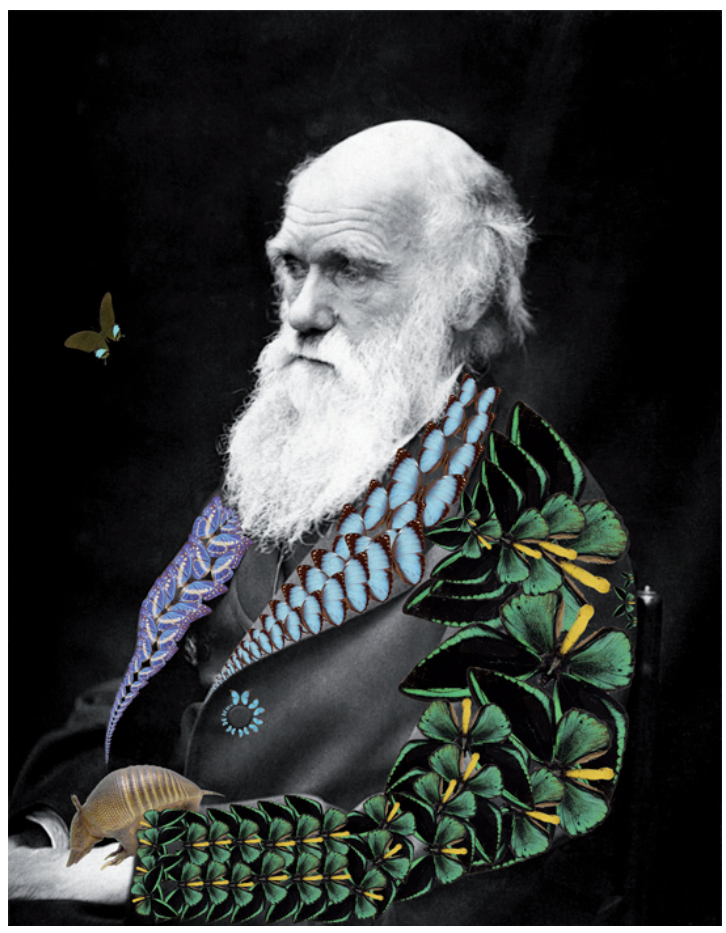




\section{The Stakes of Diversity and Sexual Selection: On Normative Commitments in Evolutionary Biology}

Diversity is a key political issue in contemporary societies. It is an established biological concept as well - witness the growing importance of biodiversity as a topic in the life sciences - and a recurrent subject of debate among those claiming a Darwinian allegiance. This paper is a preliminary incursion into the way debates over diversity within evolutionary biology are being articulated as inextricably scientific and political, through a focus on a recent challenge to sexual selection theory. ${ }^{1}$

What's the real story about diversity in gender and sexuality? How much diversity exists in other vertebrate species? How does diversity evolve in the animal kingdom? And how does diversity develop as individuals grow up: what roles do genes, hormones and brain cells play? And what about diversity in other cultures and historical periods, from biblical times to our own? Even more, I wondered where we might locate diversity in gender expression and sexual orientation within the overall framework of human diversity. Are these types of diversity as innocent as differences in height, weight, body proportion, and aptitude? Or does diversity in gender expression and sexuality merit special alarm and merit special treatment? (Roughgarden, 2004: 1-2).

These are the questions Joan Roughgarden, an evolutionary biologist from Stanford University, set out to answer. ${ }^{2}$ In her recent work, Roughgarden discusses an impressive body of literature, ranging from biology and biotechnology to the social sciences and religion. She draws on criticisms and/or different interpretations of published research and on her own first-hand research in ecology, from field observation to mathematical modelling, to propose an alternative view; and she locates the origin of her inquiry

\footnotetext{
${ }^{1}$ The discussion that follows is heavily indebted to philosophical pragmatism, and in particular to the work of John Dewey (1991), and close to those of philosophers of science and science studies scholars like Rouse (2002), Barad (2007), Longino (2002), Clough (2003) and Mol (1999). Although their positions are not coincident, they all propose some version of what I call the constitutive normativity of science, a theme central to feminist philosophy and social studies of science. For a more detailed discussion, see Nunes, 2008.

2 See, Roughgarden, 2004; 2009; Roughgarden et al, 2006, and the discussion in Kavanagh, 2006.
} 
in a concern with accounting for and explaining diversity in relation to sex, gender and reproduction, and the political and social implications of her views and those of her intellectual interlocutors. An appendix to one of her books (Roughgarden, 2004) presents a set of recommendations for public policy. ${ }^{3}$

Roughgarden's engagement with diversity is rooted in both her scientific work as an ecologist and evolutionary biologist and in her experience as an activist, transgender woman and her exposure to the variety of expressions of sexuality and gender in human society. Academia and academic disciplines do not fare well when addressing - or failing to address - these questions, as Roughgarden emphatically points out: “(...) each academic discipline has its own means of discriminating against diversity... all our academic disciplines should go back to school, take refresher courses in their own primary data, and emerge with a reformed, enlarged, and more accurate conception of diversity." (Roughgarden, 2004: 3).

How does Roughgarden articulate her engagement with sexual selection theory as both a scientific and political critique and how does she deal with lines of argument anchored in different and potentially conflicting normative commitments?

Darwin's The Descent of Man, and Selection in Relation to Sex (Darwin, 1981) addressed the momentous issue of the place of humans in evolution and also set the frame for subsequent treatments of sexual reproduction across species and for theoretical approaches to the evolutionary advantages of sexual reproduction. The second volume discusses sexual selection, the "third" mode of selection, besides natural and artificial selection (Darwin, 1996; 1875). Roughgarden's reading of The Descent and of its legacy in evolutionary biology takes a path which is different from previous engagements with Darwin's accounts and arguments. She actually makes a case for the need to abandon the theory of sexual selection, despite all the difficulties associated with the canonical status of Darwin and of his work, with the authority associated with the theory and with the "gravity of discrediting a discipline's master text" $(164)^{4}$ :

(...) Darwin's theory of natural selection as the creative force molding diversity seems certain to continue as the major element of evolutionary theory, even as discussion continues about the source of variation. By contrast, the third component of Darwin's theory, sexual selection, should not, in my opinion, be resuscitated (164).

This move is justified by the difficulty of smoothing over the factual difficulties associated with the theory and the belief that the theory "has promoted social injustice and that overall we'd be better off both scientifically and ethically if we jettisoned it" (164). In a later passage, this convergence of scientifically flawed and ethically objectionable

\footnotetext{
${ }^{3}$ Responses to Roughgarden's book - and her own comments on the responses - are available at http:// www.joandistrict6.com/reviews.

${ }^{4}$ Page numbers with no other indication refer to Roughgarden, 2004.
} 
features is associated with the context of Victorian England and its persistence in contemporary evolutionary biology with traits of modern societies:

Darwin conceived his theory in a society that glamorized a colonial military and assigned dutiful, sexually passive roles to proper wives. In modern times, a desire to advertise sexual prowess, justify a roving eye, and disregard the female perspective has propelled some scientists to continue championing sexual selection theory despite criticism of its accuracy (168).

Roughgarden is not alone in her criticism. She claims affiliation to a lineage of critics, explicitly quoting feminist biologists like Sarah Hrdy or Patricia Gowaty, going one step further, however, in proposing that the theory be abandoned altogether (168). But the obstacles ahead are formidable: sexual selection stands as "evolutionary biology's first universal theory of gender", resting upon Darwin's claim, "based on his empirical studies", that "males and females obey nearly universal templates", namely those of the "eager" and more passionate male and of the "coy" female. (164).

Darwin discussed the display of "showy and virile" males to be chosen by females as the explanation for the "eagerness of males and the "coyness" of females; the assumption of universal struggle among males for access to females as a universal template for social life in animal species, and the view of diversity within a species as a "hierarchy beginning with superior individuals and winding down to the 'retarded'". Darwin's theory thus postulated a "diversity-repressing and elitist" view, "stressing a weeding out of the weak and sickly and naturalizing male domination of females" (165).

These views, however, contrast with both earlier writings and some passages of his 1871 work: "In his earlier writings..., Darwin viewed diversity favorably across species within an ecological community, imagining that each species fills a special niche in nature". This contrast is related to Darwin's different assessments of diversity within and diversity between species, and this contradiction "plagues our society today, from biology and medicine to politics and law" (165). Darwin, as an "experienced naturalist", did consider what he called "exceptions" to the general pattern he described, acknowledging differences across species in the way males "acquire" females and females "choose" males or variations in the distribution of initiative and passivity between males and females, but nonetheless "privileging the narrative of the handsome warrior", with no attempt at further discussing or explaining "exceptions". (165-6).

Similar remarks are made on Darwin's failure to acknowledge that many animals "do not align with a simple sexual binary", although he was well acquainted with barnacles, which are simultaneous hermaphrodites. The same holds for sex-role reversals, which he mentioned but briefly characterized as rare, a question still lacking adequate study (166). Darwin seemed to be unaware of same sex-sexuality and "gender multiplicity in the sense of coexisting alternative reproductive and/or life history strategies within each sex", as well as of any consideration of the functions for mating other than their contribution to reproduction (166-7).

But Roughgarden also keeps a tab on Darwin's contributions which anticipated or opened up significant lines of inquiry, such as "the theory of parental investment based on the relative cost of egg and sperm"; the distinction "between traits contributing mostly to survival in the physical environment and those contributing mostly to reproduction in 
the social environment"; for "acknowledging many exceptions"; for anticipating many of the concepts still employed today"; and for "attributing evolutionary status to females", at a time when the notion that females were capable of choice was controversial (167).

Notwithstanding these contributions, Roughgarden's final assessment of Darwin's theory of sexual selection is that it

comes down to whether the underlying metaphor is correct. Is selection in a social context the natural part of artificial selection for show? Does social life in animals consist of discreetly discerning damsels seeking horny, handsome, healthy warriors? Is the social dynamic between males limited to fighting over the possession of females? Does diversity within a species reflect a hierarchy of genetic quality? (167)

The assessment of contemporary versions of sexual selection theory is more severe: it makes "matters worse by adding new mistakes, morphing what Darwin actually wrote into a caricature of male hubris", the major ones being, first, the reliance on what Roughgarden calls the "expensive-egg-cheap-sperm-principle", which would explain the alleged persistence of the showy male and the coy female pattern but is based on an "accounting mistake that Darwin did not make": "Darwin referred to the total energy expended by each sex in reproductive effort over a lifetime as being equal. The second mistake is the elevation of "deceit into an evolutionary principle":

Darwin claimed that warfare to secure control over females is the universal social dynamics among males. Therefore, cooperative relations, especially those between members of the same sex, appear to falsify the social template that Darwin claims is universal. The contemporary work-around is to postulate deceit. Today's sexual selectionists have produced a proliferation of "mimicries": sexual mimicry, female mimicry, egg mimicry, and so forth. By postulating these types of mimicry, the spirit of warfare and conflict is preserved but driven underground, turned into guerrilla combat. Yet in no case have any of the mimics been shown to be fooling any other animal, and the circumstances suggest that the animals are in fact perfectly aware of what is happening. The sexual-selectionist picture of nature is not pretty. Not correct either (168).

In other words, given the status of evolutionary theory in Western conceptions of the world, of nature and of humanity, is it possible to frame debates within the field by drawing a boundary between matters of fact and matters of concern (Latour, 2005) which reach beyond disciplinary worlds?

Roughgarden is not just arguing for an alternative, but equally legitimate, position within the space of evolutionary science. ${ }^{5}$ She indicts the positions she criticizes for failing

\footnotetext{
${ }^{5}$ Roughgarden's alternative approach to sexual selection is what she names social selection, and is presented and discussed in detail in Roughgarden, 2009.
} 
to live up to adequate standards of scientific evidence and argument, but she also attacks the failure of those positions to engage with the consequences of what they stand for scientifically for those who are affected by it - be they humans or non-human living beings.

Roughgarden's approach may be described as an instance of what John Dewey called inquiry, "the controlled or directed transformation of an indeterminate situation into one that is so determinate in its constituent distinctions and relations as to convert the elements of the original situation into a unified whole" (Dewey, 1991: 108). The "indeterminate situation" arises from the critical questioning, both scientific and political and moral, of sexual selection as a theory and as a normative statement on the way the world is. It opens up a space for scrutiny of the empirical and experiential record and for setting it against established theoretical and political statements. Inquiry is an active and collaborative involvement with the world, a work of discovery which redefines the status of earlier commitments or hypotheses and allows matters of concern and matters of fact to emerge as mutually defining. It allows a convergence towards a new "determinate" situation - expressed in a theoretical framework and/or a set of political recommendations - which, in turn, is open to further inquiry as new challenges arise to prevailing claims to scientific and moral truth, themselves viewed as "warranted assertibilities" (Dewey, 1991), to be put to the practical test of their effects in the world. Roughgarden's inquiry does not leave her initial questions and commitments unchanged. Engaging with the research record, with theoretical debates and with her own work as a biologist allows the triggering of questions and moral and political commitments to be extended, complemented and revised, emerging in the end as a set of renewed commitments, more robustly anchored in a personal and collective journey through diversity in nature, culture and religion, but also open to new challenges. ${ }^{6}$

\section{Bibliography}

BARAD, Karen, 2007, Meeting the Universe Halfway. Durham, North Carolina: Duke University Press.

DARWIN, Charles, 1996 [1859] The Origin of Species. Oxford: Oxford University Press.

DARWIN, Charles, 1981 [1871] The Descent of Man, and Selection in Relation to Sex. Princeton: Princeton University Press.

DARWIN, Charles, 1998 [1875], The Variation of Animals and Plants under Domestication. Baltimore: Johns Hopkins University Press (2 volumes).

DESMOND, Adrian, and MOORE, James, 2009, Darwin's Sacred Cause: How a Hatred of Slavery Shaped Darwin's Views on Human Evolution. Boston and New York: Houghton Mifflin Harcourt.

DEWEY, John, 1991 [1938], Logic: A Theory of Inquiry. The Later Works, Volume 12. Carbondale: Southern Illinois University Press.

KAVANAGH, Etta (ed.), 2006, “Debating Sexual Selection and Mating Strategies”, Science, 312: 689-697. LATOUR, Bruno, 2005, Reassembling the Social. Oxford: Oxford University Press.

\footnotetext{
${ }^{6}$ Desmond and Moore (2009) have brilliantly shown how the whole of Darwin's work was inextricably driven by his scientific and moral commitments, and in particular by the "sacred cause" of opposing slavery and demonstrating the common descent of all human beings.
} 
LLOYD, Elisabeth A., 2008, Science, Politics and Evolution. Cambridge: Cambridge University Press.

MOL, Annemarie, 1999, "Ontological Politics: A Word and Some Questions", in John Law and John Hassard (eds.), Actor Network Theory and After. Oxford: Blackwell Publishers.

NUNES, Joāo Arriscado, 2008, "O resgate da epistemologia"”. Revista Crítica de Ciências Sociais, 80: 45-70.

ROUGHGARDEN, Joan, 2004, Evolution's Rainbow: Diversity, Gender, and Sexuality in Nature and People. Berkeley: University of California Press.

ROUGHGARDEN, Joan, Meeko Oishi and Erol Akçay, 2006, "Reproductive Social Behavior: Cooperative Games to Replace Sexual Selection”, Science, 311: 965-969.

ROUGHGARDEN, Joan, 2009, The Genial Gene: Deconstructing Darwinian Selfishness. Berkeley: University of California Press.

ROUSE, Joseph, 2002, How Scientific Practices Matter. Chicago: University of Chicago Press. 